\title{
The Challenges Facing Public Secondary School Principals in the Arab Regions in Beersheba (An empirical study)
}

\author{
Munaem Alian Abu Arar \\ Israel - Ararh an-Naqab - Beersheba \\ $\mathrm{PhD}$ student majoring in educational administration at in the Arab American University- Ramallah Branch \\ Email: M3shhed@gmail.com \\ Khitam Shehdh Abu Arar \\ Israel - Ararh an-Naqab - Beersheba \\ Email:Khitamarat@gmail.com \\ Hisham Naef Abu Arar \\ Israel - Ararh an-Naqab - Beersheba \\ Email:Heshamamon@gmail.com
}

\begin{abstract}
The researchers explored the challenges facing public secondary school principals in the Arab regions in Beersheba. The population involves all the public secondary school principals in the Arab regions in Beersheba. The researchers selected a purposive sample consisting from 30 female and male principals from 30 public secondary school located in the Arab regions in Beersheba. They obtained data from them through interviewing them. The interviews were held through Skype. They were recorded to analyse data later on. The researchers took the permission of respondents to record the interview. After holding the interviews, the researchers found that the challenges facing the targeted principals. Such challenges include: 1)- Students-related challenges, 2)Parent-related challenges, 3)-Teacher-related challenges, 4)-Administrative challenges and 5)-other challenges. The researchers recommend increasing the administrative powers granted to principals at the public secondary school principals in the Arab regions in Beersheba. They recommend making amendments to the standards that govern the process of assessing teachers.
\end{abstract}

Keywords: Challenges, public secondary schools, principals, Beersheba, Israel, Arab regions.

DOI: $10.7176 / \mathrm{JEP} / 12-17-09$

Publication date:June $30^{\text {th }} 2021$

\section{Introduction}

The significance of the duties and functions carried out school principals can't be overlooked. Such duties include: duties related in the field of assessment, duties in the field of planning and duties in the field of social field. For instance, principals are responsible for attending the social events and celebrations of teachers and the administrative staff. They are responsible for setting annual and semester plans for administrative tasks and engaging the staff in the process of setting plans. They are responsible for assessing the administrative and educational staff (Mansi et al., 2014). They are responsible for making decisions, delegating powers, promoting team work spirit, and creating a work environment that promotes creativity. They are responsible for encouraging teachers to use modern teaching methods (Al-Jawabreh, 2009).

Principals are responsible for motivating the educational and administrative staff and encouraging them to work. They are responsible for strengthening the social relationships between the employees at school. They are responsible for strengthening the students' social relationships with each other. They are responsible for ensuring that all employees comply with laws and regulations. They are responsible for supervising teachers while teaching and assessing students. They must keep monitoring the pass and fail percentages in courses to detect any problem (Al-Jawabreh, 2009). They are responsible for raising the school performance and delivering services of high quality in the educational field (Parveen et al., 2021),

Despite the significance of the principals' role and duties, there are several challenges faced by principals. Such challenges include: personal, financial, technical and administrative challenges. In terms of the administrative challenges facing principals, they include: having many tasks assigned to principals and having poor communication and coordination between the school administration and the directorate of education. They include: having many administrative constraints that hinder principals from showing creativity. They include: having poor communication and planning skills by principals. They include: the poor implementation of the accountability principle for holding teachers accountable. They include: having unclear standards for regulating the powers of principals (Al-Shamri, 2019). 
In terms of the technical challenges facing principals, they include: having teachers with poor motivation to work and the poor cooperation between principals and academic supervisors. They include: the lack of the professional development programs that target principals and having teachers with poor educational competencies. They include: having teachers with poor competencies in the field of ICT. They include: having teachers who aren't cooperative and having vague standards for assessing the school staff (Al-Shamri, 2019).

In terms of the financial challenges facing principals, they include, the poor maintenance services and the poor financial incentives provided for principals. They include: the inadequate space of the school and having unsuitable playgrounds. They include: having poor security measures at school and the lack of the modern technologies at school. They include: not having internet service at school (Al-Shamri, 2019).

In terms of the personal challenges facing principals, they include: having poor relationships between the principal and some teachers. They include: the negative influence of the principal's personal problems on his/her performance. They include: the principal's lack of knowledge about the regulations and having principals suffering from health problems. They include: the principal's poor ability to handle student-related problems (Al-Shamri, 2019).

Principals face difficulty in addressing students' disruptive behaviour. They suffer from having a poor bonus system which negatively affects the performance of the staff. They suffer from having people in the administrative and educational staff who resist the changes. They suffer from the lack of financial resources. They suffer from having to wait a long time for carrying out the procedures needed to execute administrative decisions (Mansi et al., 2014).

Other challenges faced by principals include: having teachers who aren't concerned in following up the students of poor academic performance nor setting plans for improving the performance of those students. They include: having teachers who aren't concerned in developing talented and gifted students. They include: having many parents who don't follow up the academic performance of their children. The refrainment of parents from following up their children's performance negatively affects such performance (Mansi et al., 2014).

Several researchers published research articles about the problems faced by school principals in Israel (e.g. Arar (2017)). However, none of the researchers carried out an investigation about the challenges facing public secondary school principals in the Arab regions in Beersheba. Hence, the researchers believe that there's a need for writing and publishing an article about this issue. Therefore, the problem of those study manifests in the following question: (what are the challenges facing public secondary school principals in the Arab regions in Beersheba?)

\section{Objectives}

The researchers explored the challenges facing public secondary school principals in the Arab regions in Beersheba. To be specific he explored:

-The student-related challenges faced by the public secondary school principals in the Arab regions in Beersheba -The parent-related challenges faced by the public secondary school principals in the Arab regions in Beersheba

-The teacher-related challenges faced by the public secondary school principals in the Arab regions in Beersheba

-The administrate-related challenges faced by the public secondary school principals in the Arab regions in Beersheba

-The other challenges faced by the public secondary school principals in the Arab regions in Beersheba

\section{Questions}

The researchers sought answering this question: (what are the challenges facing the public secondary school principals in the Arab regions in Beersheba?). To be more specific, they aimed to answer the questions below Q.1. What are the student-related challenges faced by the public secondary school principals in the Arab regions in Beersheba?

Q.2. What are the parent-related challenges faced by the public secondary school principals in the Arab regions in Beersheba?

Q.3. What are the teacher-related challenges faced by the public secondary school principals in the Arab regions in Beersheba?

Q.4. What are the administrative-related challenges faced by the public secondary school principals in the Arab regions in Beersheba?

Q.5. What are the other challenges faced by the public secondary school principals in the Arab regions in 
Beersheba?

\section{Significance}

This study is significant because it's the first study that explored the challenges facing public secondary school principals in the Arab regions in Beersheba. It's significant because it provides officials at the Israeli Ministry of Education with knowledge about the challenges facing those principals. Providing those officials with such knowledge shall facilitate the process of setting plans and programs for addressing such challenges. It shall contribute to raising the performance of principals and the overall performance of the targeted schools. It shall contribute to raising the quality of the services provided by the targeted schools. It shall contribute to implementing the visions and goals of the targeted schools. This study is significant because it serves as a significant references for the ones interested in carrying out studies about the challenges facing principals.

\section{Limits}

The researchers carried out their investigation during the $2^{\text {nd }}$ semester/ academic year (2020/2021). They target the public secondary schools in the Arab regions in Beersheba.

\section{Definition:}

- Challenges (Theoretical definition): a stimulating task or problem (Merriam-Webster)

- Challenges (Operational definition): They refer to the challenges facing public secondary school principals in the Arab regions in Beersheba

\section{Theoretical framework}

There are several challenges faced by principals. According to Arar (2018), such challenges include: the lack of emotional support and professional assistance that are provided for principals. They include the quick transition from practicing the teaching profession into practicing the administration profession. They include: the difficulty of creating an organizational culture that comply with the vision of the principal. They include: the dominant belief that the principals' role is exclusively a male role (Arar, 2018). They include: the difficulty faced by principal in choosing the suitable leadership strategy (Al-Shamri, 2019).

The challenges faced by principals include: having principals who suffer from health problems and principals who suffer from personal problems. Both of those problems (i.e. the health and personal problems) negatively affect the performance of principals. The challenges faced by principals include: providing the school buildings with maintenance services of poor quality. They include: the absence of incentives system for motivating teachers to conduct studies and the absence of incentives system for motivating gifted student to exert more effort. They include: the poor cooperation between the principals from one hand and teachers, supervisors and officials at the directorates of education from another hand (Al-Shamri, 2019).

The challenges faced by principals include: 1)- Leadership challenges 2)- Challenges related to the school context, 3)- Challenges related to stakeholders. In terms of the leadership challenges, they include: having principals who lack the knowledge and skills needed for managing and leading the school. They include: facing a challenge by principals in achieving a balance between personal life and professional life. The greater the responsibilities assigned to principals, the greater the severity of achieving such a balance would be. The leadership challenges include: the lack of the leadership training programs that aim at developing principals professionally. The lack of such programs shall hinder principals from using technology, raising students' achievement and carrying out administrative daily tasks effectively (Adams, \& Muthiah, 2020).

In terms of the school context-related challenges that are faced by principals, they include: the multiple roles of principals. Such roles include: acquiring resources, making strategic plans, developing budgets, and managing the public relations. The challenges related to the school context include: the lack of trained staff. For instance, many schools lack employees who are capable of using technology effectively. In addition, many schools lack teachers who are capable of teaching their subjects effectively. The challenges related to the school context include: challenges related to disciplining students. For instance, there are students who suffer from smoking and drugs. (Adams, \& Muthiah, 2020).

The school context-related challenges that are faced by principals include: the inadequacy of the facilities and resources (IFR) at school (e.g. technological resources, software, and hardware). They include: financial constraints. The lack of funds negatively affects the school planning process and principals' ability to run the school effectively. It hinders principals from doing their responsibilities and duties efficiently. It hinders the 
school from repairing the resources (e.g. repairing computers). In terms of the challenges related to stakeholders, they include: the negative attitudes that some parents have towards principals. Some parents doubt the principals' ability to run the school. Such negative attitudes and doubts are attributed sometimes to racial discrimination or gender-based discrimination. The challenges related to stakeholders include: constraints enforced by the Ministry of Education. The latter constraints include: limited time to carry out certain tasks, and the absence of policies to regulate certain issues. They include: the interference of the Ministry of Education in the decision making process carried out by principals (Adams, \& Muthiah, 2020).

According to U-Sayee and Adomako (2021), the challenges that are faced by principals include: having teachers who lack experience. Due to the lack of experience, the teacher may fail in preparing the lesson plan as required. The challenges faced by principals include: the lack of the resources needed in the educational process. They include: the limited number of teachers and having crowded classrooms. Having crowded classrooms hinder teachers from monitoring all students. The challenges faced by principals include: the poor behaviours of some teachers and students. Students' bad behaviour include: stealing acts, drinking alcohol, gambling and the use of profane language (U-Sayee and Adomako, 2021).

According to Parveen et al. (2021), the challenges that are faced by principals include: inadequate physical facilities, lack of teacher professional development programs, and having a great burden of paperwork and administrative tasks enforced on principals. They include: having limited administrative powers, lack of instructional materials and equipment, and shortage in the number of teachers. They include: challenges in disciplining students and having frequent amendments to educational policies. They include: lack of parental support and involvement and teachers' low salaries. They include: teachers' low job satisfaction level. They include: the poor competence of teachers in the field of ICT (Parveen et al., 2021).

\section{Previous Studies:}

Onderi, \& Makori (2013) explored the challenges faced by principals in the secondary schools located in Nyamira, Kenya. A descriptive approach was used. A survey was created by the researchers to obtain data. Data was obtained from 81 principals working at the secondary schools located in Nyamira, Kenya. It was processed through SPSS program. The researchers found that such challenges include: financial challenges which lead to having scarcity in the learning resources and failure in attracting and retaining qualified teachers. The challenged faced by principals include: lack of resources (e.g. playground, furniture and sports facilities). They include: students' behavioural problems (i.e. drinking alcohol and drug addiction, devil worship, bullying, violence, absenteeism, and teenage pregnancy). They include: the inadequacy of the staff and having unqualified employees and teachers.

Salman (2007) explored the problems which are faced by school administrations and the methods of addressing them in Diyala. The sample involves 600 individuals. It includes: secondary, intermediate and primary school principals, head of departments, and supervisors. The researcher found that such problems include: students' poor academic achievement, crowded classrooms, the lack of cooperation between parents and administration. They include: having teachers who refrain from using educational aids. The school libraries lack the books that meet the needs of students and educators. There is a great burden enforced on school principals.

Lahwany (2007) explored the problems faced by the principals in UNRWA basic schools from the view of teachers and principals in the Northern provinces in Palestine. The sample involves 27 female and male principals and 221 female and male teachers. Those teachers and principals were sampled through the random stratified sampling method. A survey was created and used for obtaining data. It targets the following areas: curricula, teacher affairs, student affairs, local community, school building \& equipment, educational devices $\&$ aids, and the use of technology in school. In terms of curricula-related problems, parents complained about their failure to understand the curricula which hindered them from teaching their students. The content of some curricula don't fit with students' capabilities. In terms of teachers' affairs-related problems, the moral of some teachers is low. Some teachers teach courses that don't fall under their major (Lahwany, 2007).

In terms of students' affairs-related problems, classrooms are overcrowded and students show poor academic performance. Many students aren't committed to doing their assignments. Many students are absent without giving any excuse. In terms of the local community-related problems, the cooperation of parents with school is low in terms of amending their children's behaviours. The latter problems include: the poor parents' engagement in school activities and parties. They include: the poor financial support granted to school by the local community. They include: having many parents who aren't concerned in asking about their children's 
performance and behaviour in school (Lahwany, 2007).

In terms of the school building \& equipment-related problems, there are scarcity in the number of classrooms, activity halls and bathrooms. There is failure in meeting some requirements in the school environment, such as: the requirement related to lighting and ventilation. Some teachers face difficulty in using some equipment at school. In terms of the educational devices \& aids-related problems, the teachers have poor abilities in developing educational aids. The number of computer devices in school are scarce. The number of places that are dedicated for keeping the educational aids are scarce. The number of the resources rooms are scarce in schools. In terms of the problems related to the use of technology in school, the extent of using technology by teachers in the educational process is low (Lahwany, 2007).

Wildy et al. (2010) explored the challenges which are faced by principals in Turkey and Australia. Data was collected from 50 Australian principals. It was also collected from 60 Turkish principals. It was collected from those principals in Turkey and Australia through a survey. According to principals in Turkey and Australia, achieving a balance between personal life and professional life and managing the school budge are major challenges. According to principals in Turkey and Australia, the availability of resources and cooperating with parents aren't challenges. The researchers found that establishing positive relationship with the staff is more challenging for Turkish principals than the Australian ones. The female principals, the Australian principals and the principals in remote and rural areas are more prepared than the other principals for doing their tasks.

Preetik, and Priti (2013) explored the challenges which are faced by principals in India. They carried out their study through adopting a descriptive approach and selecting a sample consisting from five (5) principals. Those principals were chosen from 5 schools. They were interviewed to obtain data from them. The researchers concluded that such challenges include: challenges related to students. For instance, principals face challenges related to disciplining students and students' academic achievement, absence, safety and security. They face problems represented in having students running away from school during the school working hours. They suffer from the lack of parental support and attention for students. They suffer from the lack of cooperation between parents and school. The researchers concluded that principals face difficulty in achieving a balance between professional life and personal life. Principals also suffer from having additional work load and having to stay at school to work for extra hours.

Hamayel (2018) explored the problems which are faced by public secondary school principals in Palestine. A twenty-seven item survey was used. The survey forms were passed to 437 female and male principals. 380 survey forms were retrieved and analysed. The survey targets three areas (i.e. school-related problems, teacherrelated problems and technical problems). Several results were reached. For instance, the severity of the problems which are faced by public secondary school principals in Palestine is moderate. In terms of the schoolrelated problems, they include: the absence of internet service and resources rooms at schools. They include: having narrow and inconvenient classrooms. They include: having inconvenient school canteens and playgrounds. They include: the inconvenience of the principal room. In addition, the public safety measures aren't effective (Hamayel, 2018)

In terms of the teacher-related problems, they include: the low salaries of teachers, the poor professional development of teachers and lack of the sense of belonging among some teachers towards the school. They include: having teachers who work in another job after the school working hours. They include: recruiting teachers who don't have any training courses. They include: the absence of teachers, and having teachers who have poor capabilities in using technology. In terms of the technical problems, they include: having a great burden enforced on principals, and the low bonus given to principals. They include: the scarcity of financial resources, and the inactive role of parent council. They include: the lack of the meetings held between the principals and the ones working in the directorate of education (Hamayel, 2018)

Pineda-Báez et al. (2019) explored the challenges which are faced by novice principals in Colombian schools. They obtained the data they need through making interviews with 37 novice principals. Those principals were chosen from Colombian schools (including the schools in rural and urban areas). The researchers found that principals face challenges in managing the students' bad behaviours. Such bad behaviours involve disputes, physical aggression, fights and bullying behaviour carried out by students against their colleagues. The challenges faced by principals include having overcrowded classrooms and infrastructural challenges. They include: difficulty in promoting a sense of belonging among students and a good school climate. They include: dealing with students who suffer from addicted parents and family violence, neglect and abuse. They include: having fraught relationships with some teachers and the absence of teachers. They include: the poor pedagogical 
practices of teachers. They include: lack of the appreciation that must be shown for principals for their efforts. They include: the poor parental engagement in the educational process.

\section{Methodology}

9.1. Approach

Through adopting a descriptive approach, the researcher explored the challenges facing public secondary school principals in the Arab regions in Beersheba.

\subsection{Sample and Population}

The population involves all the public secondary school principals in the Arab regions in Beersheba. The researchers selected a purposive sample consisting from 30 female and male principals from 30 public secondary school located in the in the Arab regions in Beersheba. They obtained data from them through interviewing them. The interviews were held through Skype. They were recorded to analyse data later on. The researchers took the permission of respondents to record the interview. Table (1) shows the gender of the sampled public secondary school principals

Table (1): The gender of the sampled public secondary school principals

\begin{tabular}{|l|l|l|l|}
\hline Variable & Category & Frequency & Percentage \\
\hline \multirow{2}{*}{ Gender } & Male & 20 & 66.6 \\
\cline { 2 - 4 } & Female & 10 & 33.33 \\
\hline
\end{tabular}

$\mathrm{N}=30$

9.3. Instrument

The researchers used the interview data collection method for obtaining data. Through the interview, the respondents were asked about the challenges they face at work. They were asked the following questions Q.1 What are the student-related challenges that you face at the workplace as a principal?

Q.2. What are the parent-related challenges that you face at the workplace as a principal?

Q.3. What are the teacher-related challenges that you face at the workplace as a principal?

Q.4. What are the administrative-related challenges that you face at the workplace as a principal?

Q.5. Are other challenges that you face? If so, please, mention them

The interviews were held through Skype. They were recorded to analyse data later on. The researchers took the permission of respondents to record the interview.

\subsection{Validity of the Instrument}

The researchers consulted two faculty members. They asked them whether the questions of the interview are clear and capable of meeting the goal sought from the research. The two faculty members suggested that the questions are clear and enable the researchers to meet the goals they seek meeting. They added that the question cover various types of challenges

9.5. Analysis of data

To analyse data, the researchers listened to the recorded interviews several time. Through listening to them, they were capable of paying attention to all the details and reaching results about the challenges. They used a table to present the study's results in an organized and clear manner.

\section{Results and discussion}

What are the challenges facing public secondary school principals in the Arab regions in Beersheba?) After analysing the recorded interviews, the researchers found that there are several challenges facing public secondary school principals in the Arab regions in Beersheba. Some of those challenges are shown below:

a) Students-related challenges:

1) Difficulty in managing the bad behaviours carried out by students

7 principals suggested that they suffer from difficulty in addressing the bullying behaviours carried out by students. 12 principals suggested that they suffer from having disputes between students. 4 principals suggested that they suffer violence at school.

This result is consistent with the one reached by Pineda-Báez et al. (2019).

2) The difficulty in raising the poor achievement of some students

11 principals suggested that they suffer from difficulty in raising the poor achievement of some students. For instance, one of the principals stated: 'I face difficulty in determining the measures that must be taken to raise 
the low achievement of some student in courses"'.

This result is consistent with the one reached by Salman (2007).

b) Parent-related challenges:

1) Having parents who don't follow up the achievement of their sons /daughters

14 principals suggested that some parents who don't follow up the achievement of their sons /daughters. For instance, one of the principals stated: 'Some parents don't track the achievement of their sons/ daughters and refrain to cooperate with the school administration to raise such achievement"

This result is consistent with the one reached by Salman (2007).

2) The poor engagement of some parents in the school parties and activities:

3 principals suggested that some parents refrain from engaging in school parties and activities. For instance, one of the principals stated: 'There are parents who never participated in the school activities'.

This result is consistent with the one reached by Lahwany (2007).

c) Teacher-related challenges

1) Having teachers who aren't motivated to work

8 principals claimed that they have teachers who aren't motivated to work. Such lack of motivation may be attributed to the teachers' dissatisfaction with the way in which the principal run the school. For instance, one of the principals stated: 'I have teachers who were very active in the past. However, today, they aren't motivated to work and make complaints all the time".

2) Having teachers who aren't competent in using technology

7 principals claimed that they have teachers who aren't competent in using technology. For instance, one of the principals stated: 'Some teachers at school have poor computer skills. They are in need for getting professional development courses about the way of using computer',

This result is consistent with the one reached by Parveen et al. (2021)

3) Having fraught relationships with some teachers

6 principals suggested that they have fraught relationships with some teachers. For instance, one of the principals stated: (Some teachers are just aggressive. Thus, it's difficult for me to have good relationships with those teachers. That negatively affects the overall school performance).

This result is consistent with the one reached by Pineda-Báez et al. (2019).

4) The poor competency of teacher in the field of pedagogy

8 principals suggested that some teachers don't employ the modern teaching methods. For instance, one of the principals stated: (Some teachers don't have any idea about the modern teaching methods).

4 principals suggested that some teachers don't have the required competency in the field of assessment. For instance, one of the principals stated: (Some teachers don't take the individual differences between students into consideration when assessing students). Another principals stated: (Some teachers don't use a variety of assessment methods).

This result is consistent with the one reached by Pineda-Báez et al. (2019)

d) Administrative challenges

1) Having a great amount of tasks

13 principals suggested that there are many tasks enforced on them. This result is consistent with the one reached by Hamayel (2018). For instance, one of the principals stated: ' There are many tasks that I have to carry out. I wish if I can assign some of those tasks to the vice principal. However, that can't be done. I must carry out those tasks by myself",

7 principals suggested that they have physically exhausted and feel tired due to having numerous tasks. For instance, one of the principals stated: "'I have been feeling lately extremely tired, because there are many tasks assigned to me'".

2) Having limited administrative powers in some issues

2 principals claimed that they have limited powers. For instance, one of the principals stated: 'I must be provided with more administrative powers",

This result is consistent with the one reached by Parveen et al. (2021)

3) Having unclear standards for assessing teachers:

3 principals claimed that the standards used for assessing teachers aren't clear. They added that this challenge hinder them from assessing teachers in a scientific manner and reaching accurate results. For instance, one of the 
principals stated: 'I believe that amendments must be made to the standards that govern the process of assessing teachers. That's because such standards are vague and unclear',

This result is consistent with the one reached by Al-Shamri (2019).

\section{e) Other challenges:}

One of the principals suggests that his personal problems sometimes negatively affect his performance at the workplace. He adds that such problems sometimes negatively affect the quality of his decisions. To be specific, he states: ' 'Sometimes, I come to work with being negatively influenced by my personal problems. Such problems sometimes hinder me from showing a good performance. They sometimes hinder me from taking the right decision. They sometimes hinder me from implementing plans as required'.

This result is deemed consistent with the one reached by Wildy et al. (2010)

In order to present the challenges faced by public secondary school principals in the Arab regions in Beersheba in a summarized manner, the researchers designed the table below

Table (2): The challenges faced by public secondary school principals in the Arab regions in Beersheba

\begin{tabular}{|l|l|l|}
\hline No. & Type of challenge & Challenges \\
\hline 1 & $\begin{array}{l}\text { Students-related } \\
\text { challenges: }\end{array}$ & $\begin{array}{l}\text { 1)-Difficulty in managing the bad behaviours carried out by } \\
\text { students } \\
\text { 2)-The difficulty in raising the poor achievement of some } \\
\text { students }\end{array}$ \\
\hline 2 & Parent-related challenges: & $\begin{array}{l}\text { 1)- Having parents who don't follow up the achievement of } \\
\text { their sons /daughters } \\
\text { 2)- The poor engagement of some parents in the school } \\
\text { parties and activities }\end{array}$ \\
\hline 3 & Teacher-related challenges & $\begin{array}{l}\text { 1)-Having teachers who aren't motivated to work } \\
\text { 2)-Having teachers who aren't competent in using technology } \\
\text { 3)- Having fraught relationships with some teachers } \\
\text { 4)- The poor competency of teacher in the field of pedagogy }\end{array}$ \\
\hline 4 & Administrative challenges & $\begin{array}{l}\text { 1)-Having areat amount of tasks } \\
\text { 2)-Having limited administrative powers in some issues } \\
\text { 3)- Having unclear standards for assessing teachers. }\end{array}$ \\
\hline 5 & Other challenges & $\begin{array}{l}\text { The negative impact of the principals' personal problems on } \\
\text { their performance at the workplace }\end{array}$ \\
\hline
\end{tabular}

\section{Conclusion}

The researchers found that there are several challenges facing public secondary school principals in the Arab regions in Beersheba. Such challenges include: 1)- Students-related challenges, 2)-Parent-related challenges, 3)Teacher-related challenges, 4)-Administrative challenges and 5)-other challenges. In terms of the studentsrelated challenges, the principals face difficulty in managing the bad behaviours carried out by students. They face difficulty in raising the poor achievement of some students. In terms of the parent -related challenges, they include: having parents who don't follow up the achievement of their sons /daughters. They include: the poor engagement of some parents in the school parties and activities. In terms of the teacher-related challenges, they include: having teachers who aren't motivated to work. They include: having teachers who aren't competent in using technology. They include: having fraught relationships with some teachers and the poor competency of teacher in the field of pedagogy. In terms of the administrative challenges, they include: having a great amount of tasks and having limited administrative powers in some issues. The other challenges include: negative impact of the principals' personal problems on their performance at the workplace

\section{Recommendations:}

The researchers recommend:

- $\quad$ Providing teachers in the public secondary school principals in the Arab regions in Beersheba with training courses in the pedagogy field

Providing teachers in the public secondary school principals in the Arab regions in Beersheba with training courses in the field of ICT. 
Holding more social events and celebrations at public secondary school principals in the Arab regions in Beersheba in order to improve the teacher-principal relationship.

Increasing the administrative powers granted to principals at the public secondary school principals in the Arab regions in Beersheba

-Making amendments to the standards that govern the process of assessing teachers.

\section{References}

References Published in English language:

1. Adams, D., \& Muthiah, V. (2020). School principals and $21^{\text {st }}$ century leadership challenges: A systematic review. Journal of Nusantara Studies (JONUS), 5(1), 189-210. https://doi.org/10.24200/jonus.vol5iss1pp189210

2. Arar, K. (2017). How Novice Principals Face the Challenges of Principalship in the Arab Education System in Israel. Journal of Career Development. 45(6).580-596 https://doi.org/10.1177/0894845317726392.

3. Challenge. 2011. In Merriam-Webster.com. Retrieved July 5, 2021, from https://www.merriam-webster.com/dictionary/hacker

4. Onderi, H. \& Makori, A. (2013). Secondary school principals in Nyamira County in Kenya: Issues and challenges. Educational Research International, 1(1), 67 - 90.

5. Parveen, K., Bao Phuc, T. Q., Shafiq, M., \& Wei, T. (2021). Identifying the administrative challenges encountered by the principals in low-performing public secondary schools of Faisalabad District, Pakistan. International Journal of Humanities and Innovation (IJHI), 4(1), 5-16. https://doi.org/https://doi.org/10.33750/ijhi.v4i1.101

6. Pineda-Báez, C, Bernal-Luque, R, Sandoval-Estupiñan, LY, Quiroga, C (2019) Challenges facing novice principals: A study in Colombian schools using a socialisation perspective. Issues in Educational Research 29(1): 205-222.

7. Preetik, B.; and Priti, J. (2013). A Descriptive Study on the Challenges faced by a School Principals. International Research Journal of Social Sciences, 2(5), 39-40

8. U-Sayee, C. and Adomako, E. (2021). Supervisory practices and challenges faced by senior high school principals in Greater Monrovia, Liberia: implications for quality education. Heliyon. 7(4), DOI: https://doi.org/10.1016/j.heliyon.2021.e06895

9. Wildy, H., Clarke, S., Styles, I.; Beycioglu, K. (2010). . Preparing novice principals in Australia and Turkey: How similar are their needs? Educational Assessment, Evaluation and Accountability. No. 22, $307-326$. https://doi.org/10.1007/s11092-010-9106-y

References Published in Arabic language:

10. Al-Jawabreh, F. (2009). The organizational role of the Jordanian basic school principal in the light of the Total Quality Indicators. The Educational Journal of the Educational faculty at Sohag University. 26(26), p.137, Doi: 10.21608/EDUSOHAG.2009.129473, https://edusohag.journals.ekb.eg/article 129473.html

11. Al-Shamri, A. (2019). The administrative obstacles facing primary school principals in Ha'elal and means for overcoming those obstacles dressing them from the perspective of those principals. The Arab journal for educational and psychological sciences. No. 11, p. 193-232

12. http://search.shamaa.org/FullRecord?ID=245344

13. Hamayel, H. (2018). The administrative problems faced by public secondary school principals in Palestine. The Journal of Palestine University for Research and Studies. 8(1). http://search.shamaa.org/FullRecord?ID=238861

14. Lahwany, H. (2007). The Problems that Face the UNRWA Schools Principals of the Basic Stage from the Point of View of the Headmasters and Teachers in the Governorates of North Palestine. Published MA thesis. An-Najah National University, Nablus, Palestine. http://search.shamaa.org/fullrecord?ID=40275

15. Mansi, R.; Mustafa, E. and Al-Shurman, M. (2014). School principals roles evaluation, planning and humanity from the perspective of school principals at the UNRWA schools in Jordan: Problems and proposed solutions. The International Interdisciplinary Journal of Education. 3(4). 74-90, http://search.shamaa.org/FullRecord?ID=90719

16. Salman, M. (2007). The administrative problems faced by school administrations and the methods of addressing them in Diyala. Al-Fateh Journal. No. 31, 262-282, http://search.shamaa.org/FullRecord?ID=20595 